\title{
Margaret McCartney: Fighting for the NHS's moral life
}

\author{
Margaret McCartney, general practitioner
}

Glasgow

Contracts are about to be rewritten, for GPs in England and for consultants. Junior doctors are getting a new one. Yawning gaps exist in out-of-hours GP and junior hospital rotas. Emergency department waits are increasing, as are complaints to the General Medical Council, and morale is disintegrating. Is this the NHS's decline and fall?

Doctors used to have much autonomy, leading to innovation, excellent care, and high job satisfaction-but also to exhaustion and to a few doctors taking advantage of minimal oversight.

We now have bureaucracy, intrusive checking of often irrelevant "performance" data, and an entire (expensive) industry professing to regulate us. We no longer have a moral contract to practise medicine but instead have an angst ridden, nit picking one that assumes the worst and tries to find it.

I won't resentfully add up the extra hours I worked this weekend or before my official start time, as long as I'm doing a useful job that's valuable to patients and I retain some control over my working life. If my work feels crammed with conflict, if I'm routinely pleading for referrals to be accepted, or when organisations change without consultation or consideration, then clock watching and declaiming that "it's not my job" will become natural.

In an emergency if a doctor can't work a shift, then someone who doesn't feel valued or part of a coherent service will feel no moral responsibility to help. Treat workers as mere disposable cogs in a corporate wheel, and they won't imagine or invest their future as part of it. So, no one will innovate, create, or challenge. No one will feel ownership of a shared destiny.

All of this will have to come from external management consultancies with variously laughable grasps of medicine. We're in a mess, pretending that we can do more with less, prioritising winning votes rather than fairness and without cognisance of opportunity costs-all inflamed by the recurrent misuse of statistics.

Patients are being told to expect more and to complain loudly when it's not delivered. But in what warped universe can elective surgery at the weekend be more important to deliver than emergency overnight care?

If truth is the first casualty of war, the NHS is fighting for its moral life. Meeting the needs of everyone, free at the point of need: do this first, and then we can talk. We need an evidence based NHS, released from the stranglehold of party politics that causes so much waste and angst. But we also need to backtrack, to take advantage of professionalism and to allow staff to use it.

Competing interests: See www.bmj.com/about-bmj/freelancecontributors/margaret-mccartney.

Provenance and peer review: Commissioned; not externally peer reviewed.

Published by the BMJ Publishing Group Limited. For permission to use (where not already granted under a licence) please go to http://group.bmj.com/group/rights-licensing/ permissions 